DOI: $10.17951 / 1 r p .2020 .40 .1 \cdot 101-116$

\title{
Bożena Dusza
}

Uniwersytet Rzeszowski

ORCID - 0000-0003-1294-8977

\section{INDYWIDUALNE TEORIE PEDAGOGICZNE NAUCZYCIELI NA TEMAT SZKOŁY JAKO MIEJSCA ROZWIJANIA KREATYWNOŚCI ORAZ SAMODZIELNOŚCI MYŚLENIA I DZIAŁANIA UCZNIÓW (RAPORT Z BADAŃ)}

\begin{abstract}
Streszczenie: Wprowadzenie: W badaniach nad szkołą są wykorzystywane różne kategorie. W prezentowanych badaniach wykorzystuję kategorię indywidualnych teorii pedagogicznych nauczycieli. Teorie te będąc efektem m.in. wiedzy nauczycieli wyniesionej ze studiów, ich doświadczeń zawodowych, przekonań, stereotypów, w istotny sposób wpływają na ich pracę w szkole. Cel badań: Tekst jest raportem z badań przeprowadzonych w 2019 roku wśród nauczycieli szkół podstawowych $(N=550)$. Celem badań było odkrycie indywidualnych teorii pedagogicznych nauczycieli odnoszących się do szkoły jako miejsca rozwijania kreatywności ucznia oraz jego samodzielności myślenia i działania. Metoda badań: W badaniach wykorzystano metodę sondażu diagnostycznego. Techniką była ankieta własnej konstrukcji. Wyniki: Wyniki badań, jakie otrzymano, wskazują, że $43 \%$ badanych nauczycieli jest przekonanych o tym, że kluczowym zadaniem szkoły jest przekaz wiedzy, a nie rozwój samodzielności i kreatywności uczniów. Ich osobiste teorie w tym względzie różnią się w zależności od wielkości szkoły, stażu pracy oraz poziomu kształcenia. Niepokojące jest to, że $40 \%$ badanych uważa, że aby odnieść sukces szkolny, konieczne jest rozwinięcie „szkolnego sposobu myślenia” u ucznia. Wnioski: Wyniki badań odsłaniają paradoksalną rzeczywistość, w której system szkolny nie oczekuje od uczniów radzenia sobie w świecie i nie przygotowuje do takiegoż, a wymaga kompetencji ucznia potrzebnych mu jedynie, by w tym systemie przetrwać.
\end{abstract}

Słowa kluczowe: szkoła, nauczyciel, pedagogiczne indywidualne teorie nauczycieli, kreatywność ucznia, samodzielność myślenia ucznia 


\section{WPROWADZENIE}

Badaniom szkoły mogą służyć różne kategorie. Jedną z nich, którą wybrałam dla badań własnych, jest kategoria osobistych teorii pedagogicznych nauczycieli. Teorie te zakorzenione $\mathrm{w}$ świadomości nauczycieli, a mające swoje źródło w doświadczeniach pedagogicznych, stereotypach, uprzedzeniach, przekonaniach, a także w wiedzy wyniesionej ze studiów, kursów i literatury „fachowej,” mają istotny wpływ na praktykę edukacyjną (Dusza, 2018).

Podążając tropem osobistych teorii pedagogicznych nauczycieli, skupiłam się m.in. na przekonaniach nauczycieli dotyczących szkoły jako miejsca rozwijania kreatywności ucznia oraz jego samodzielności myślenia i działania.

\section{PROBLEM I CEL BADAŃ}

Problem główny podjętych przeze mnie badań brzmi: Jakie są opinie nauczycieli na temat szkoły jako miejsca wykorzystania potencjału rozwojowego ucznia?

W tym miejscu skupię się na jednym z problemów szczegółowych, dotyczących opinii nauczycieli na temat szkoły jako miejsca rozwijania kreatywności ucznia, jego samodzielności myślenia i działania.

\section{METODA BADAŃ I CHARAKTERYSTYKA PRÓBY}

W badaniu, metodą sondażu diagnostycznego, wykorzystano ankietę własnej konstrukcji. Pytania miały charakter zamknięty, otwarty i półotwarty.

Badania, których fragment chciałabym przedstawić, zostały przeprowadzone w 2019 roku. Objęły grupę 550 nauczycieli pracujących szkołach podstawowych na terenie województwa podkarpackiego.

Spośród (244) badanych nauczycieli 44\% (244) to nauczyciele klas początkowych, pozostali - 56\% - to uczący w starszych klasach szkoły podstawowej i wygaszanych gimnazjach.

Większość badanych jest zatrudniona w średnio licznych szkołach, w których jest od 100 do 300 uczniów (52\%). Pozostali pracują w małych szkołach, do 100 uczniów (26\%), i dużych, powyżej 300 uczniów (22\%).

Największą grupę badanych stanowią doświadczeni nauczyciele o stażu pracy powyżej 15 lat (47\%), młodzi stażem nauczyciele, poniżej 5 lat, stanowią w badanej grupie 13\%. Pozostali (40\%) pracują w szkołach od 6 do 15 lat. 


\section{WYNIKI BADAŃ}

Badanym przedstawiono listę tez, w stosunku do których mieli wyrazić opinię: zgadzam się/ nie zgadzam.

\section{Wykres 1.}

Stosunek badanych do tezy „Kluczowym zadaniem nauczyciela jest nauczanie rozumiane jako przekaz wiedzy"

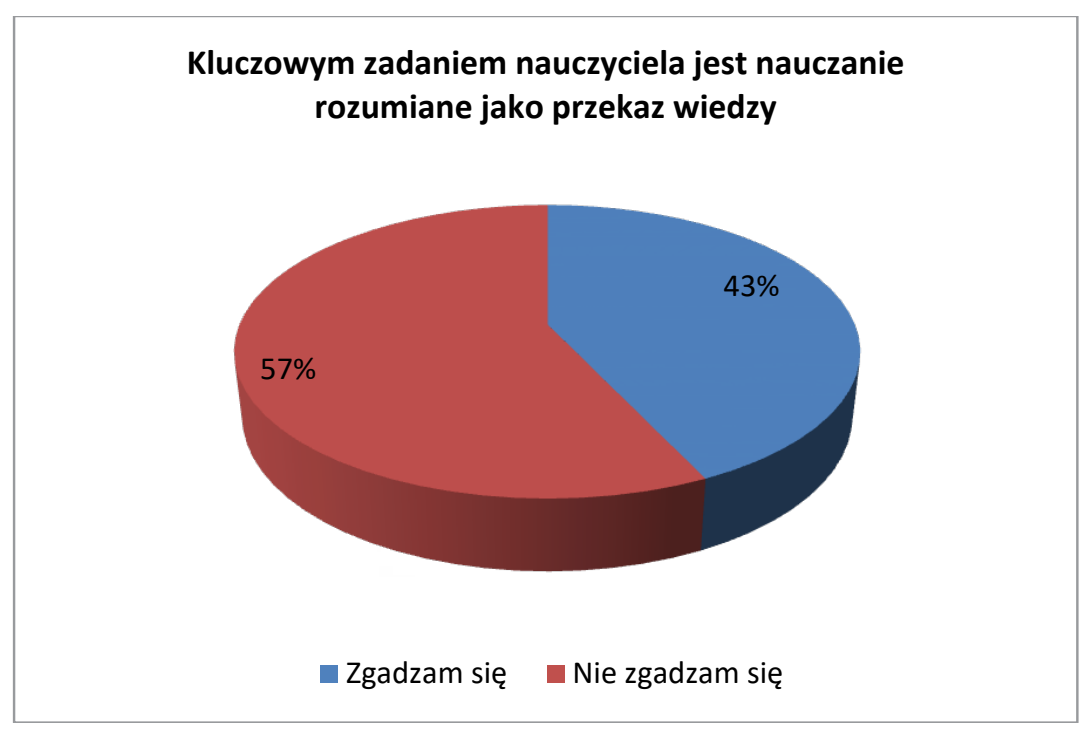

Źródło: badania własne

Poglądy badanych nauczycieli dotyczące transmisyjnej roli szkoły niemal się równoważą. Tylko niewiele ponad połowa badanych jest zdania, że rola nauczyciela nie ogranicza się wyłącznie do przekazu wiedzy, jak ma to miejsce w tradycyjnie ujmowanym procesie nauczania.

Interesująco przedstawia się analiza pod względem wielkość szkoły.

Analizując wyniki badań, można zauważyć interesującą tendencję. Im większa szkoła, tym większa skłonność nauczycieli do rozumienia swojej roli głównie jako przekaz wiedzy. W tym aspekcie najkorzystniej „wypada” mała szkoła, gdzie tylko co trzeci badany uczący w tej szkole tak rozumie swoją rolę. 
Wykres 2.

Stosunek badanych do tezy „Kluczowym zadaniem nauczyciela jest nauczanie rozumiane jako przekaz wiedzy" a wielkość szkoty, w której ucza

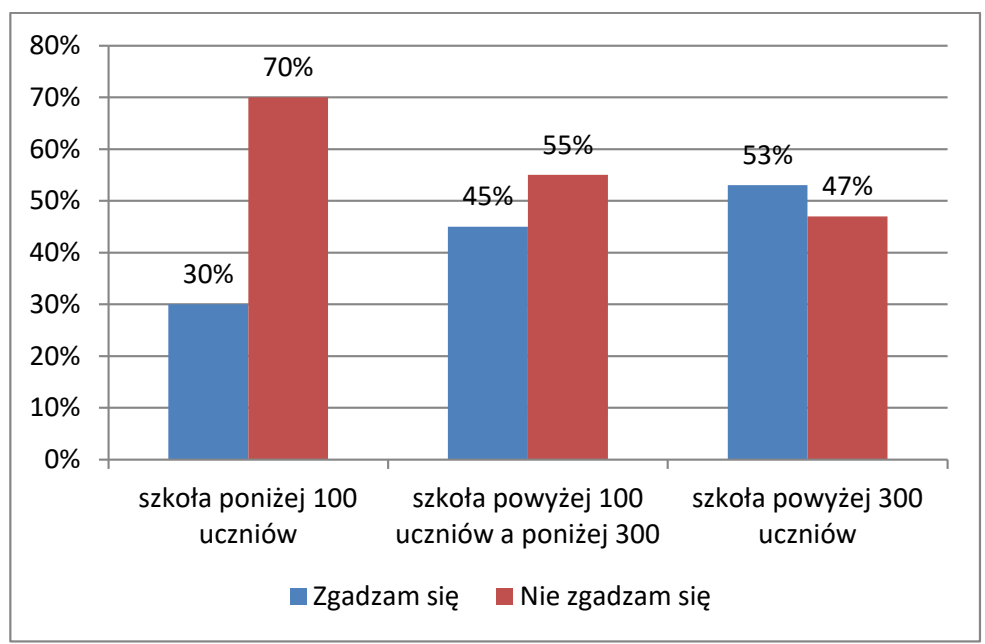

Źródło: badania własne

W przypadku stażu pracy badanych różnice też są istotne. Przedstawiono je na wykresie 3.

Wykres 3.

Stosunek badanych do tezy „Kluczowym zadaniem nauczyciela jest nauczanie rozumiane jako przekaz wiedzy" a staż pracy badanych

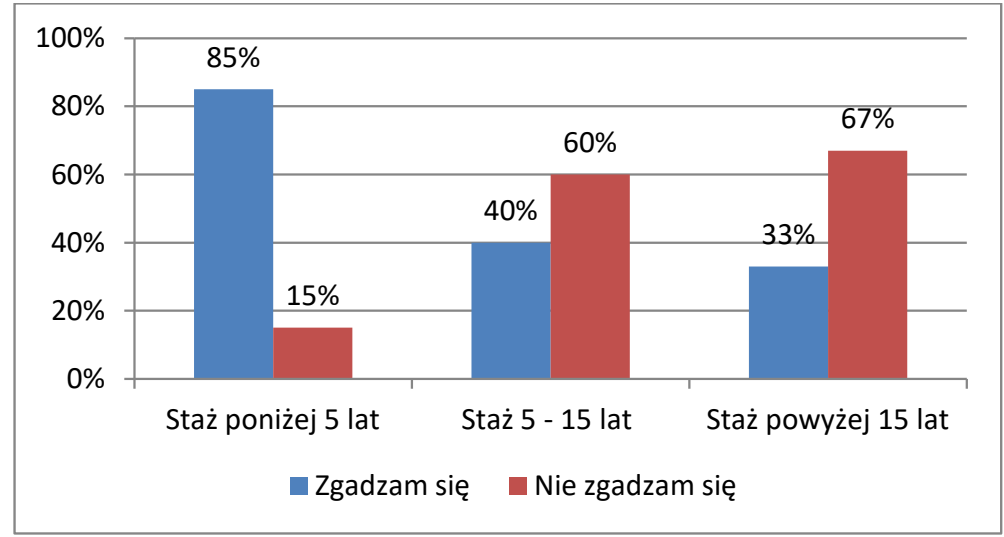

Źródło: badania własne 
Analiza danych zawartych na wykresie wyraźnie wskazuje istotne różnice pomiędzy badanymi w kwestii tego, czy kluczowym zadaniem nauczyciela jest przekaz wiedzy. W tym względzie niemal jednomyślni są młodzi nauczyciele (do 5 lat stażu pracy), którzy tak właśnie rozumieją zadania nauczyciela. W przypadku nauczycieli bardziej doświadczonych tendencja ta jest odwrotna. Tym samym potwierdza się teoria, że wraz z doświadczeniem nauczyciela wzrasta jego koncentracja, w trakcie realizacji programu, na potrzebach ucznia (Dembo, 1997, s. 36).

Na wykresie 4 przedstawiono niniejsze wyniki badań w odniesieniu do poziomu kształcenia, na jakim pracuje nauczyciel.

Wykres 4.

Stosunek badanych do tezy "Kluczowym zadaniem nauczyciela jest nauczanie rozumiane jako przekaz wiedzy" a poziom kształcenia, na jakim pracuje nauczyciel

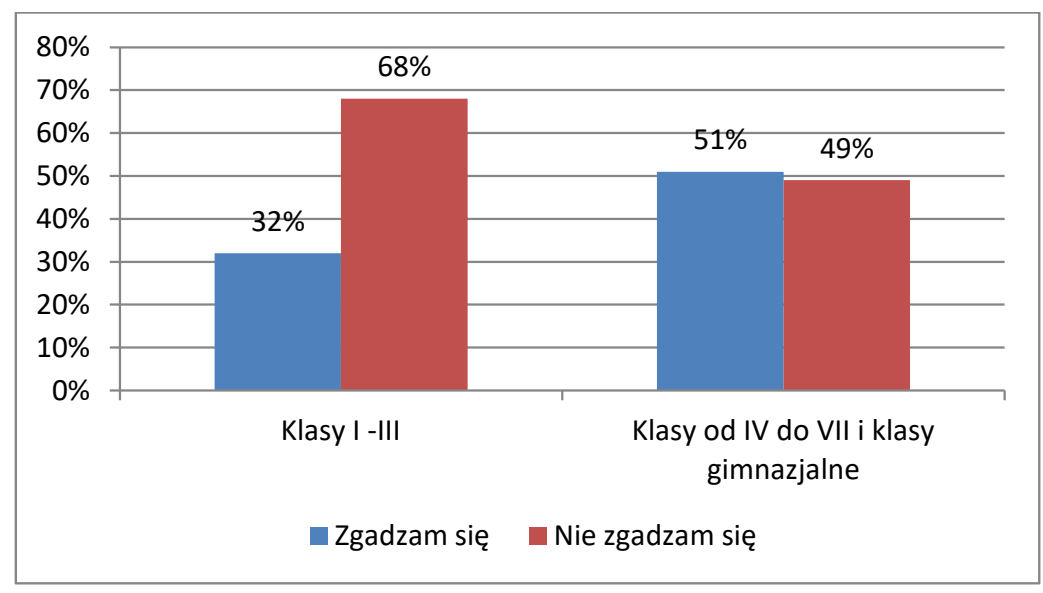

Źródło: badania własne

Wyniki badań wskazują na spodziewaną tendencję. Im wyższy poziom kształcenia, tym bardziej rozpowszechniony jest wśród nauczycieli transmisyjny model nauczania. Niepokój budzi fakt, że wśród badanych nauczycieli edukacji wczesnoszkolnej co trzeci jest skłonny twierdzić, że jego zadanie polega głównie na przekazie wiedzy. 
Wykres 5.

Stosunek badanych do tezy „Myślę, że uczniowie musza nauczyć się pewnego «szkolnego sposobu myślenia» odpowiadania na pytania, by odnieść sukces $w$ szkole”

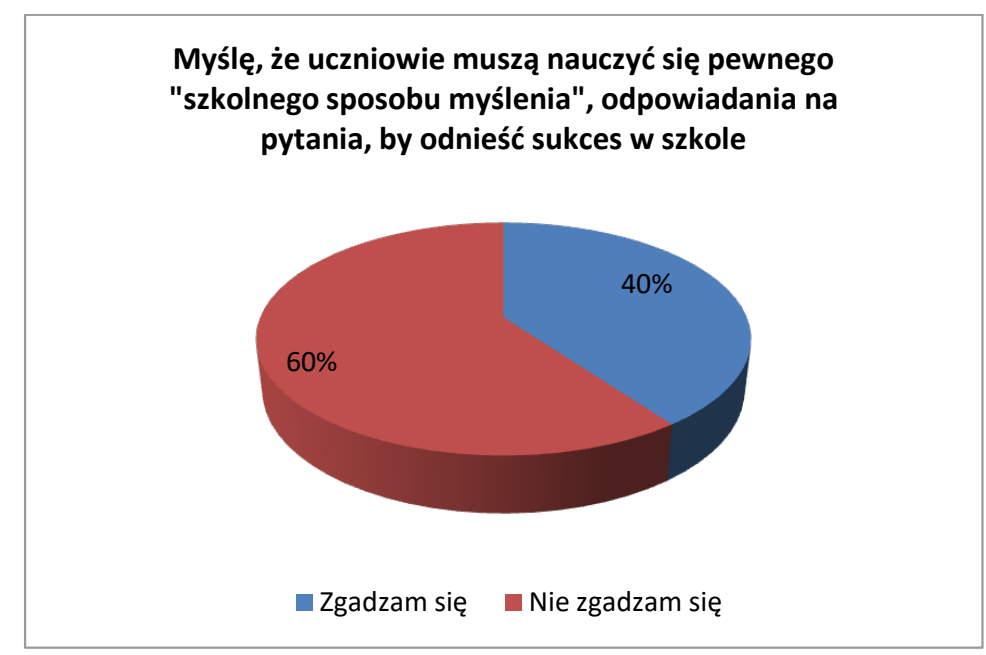

Źródło: badania własne

Spośród 10 badanych 4 jest skłonnych twierdzić, że dla szkolnego sukcesu ucznia konieczna jest pewna strategia „szkolnego sposobu myślenia”. Tym samym można domniemywać, że egzekwują od swoich uczniów myślenie tego typu, co stoi w jawnej sprzeczności z myśleniem samodzielnym czy krytycznym. Tym samym odsłania się paradoksalna rzeczywistość, w której system szkolny nie oczekuje od uczniów radzenia sobie w świecie i nie przygotowuje do takiegoż, a wymaga kompetencji ucznia potrzebnych mu jedynie, by w tym systemie przetrwać. Na takie praktyki Bennett i LeCompte (1990) używają określenia schooling. Pojawia się pytanie, czy uczeń poddany praktyce „szkolnego myślenia” będzie radził sobie w świecie. 
Na wykresie 6 przedstawiono powyższe wyniki w odniesieniu do wielkości szkoły.

Wykres 6.

Stosunek badanych do tezy „Myślę, że uczniowie musza nauczyć się pewnego «szkolnego sposobu myślenia» odpowiadania na pytania, by odnieść sukces $w$ szkole" a wielkość szkoły, w której pracuja

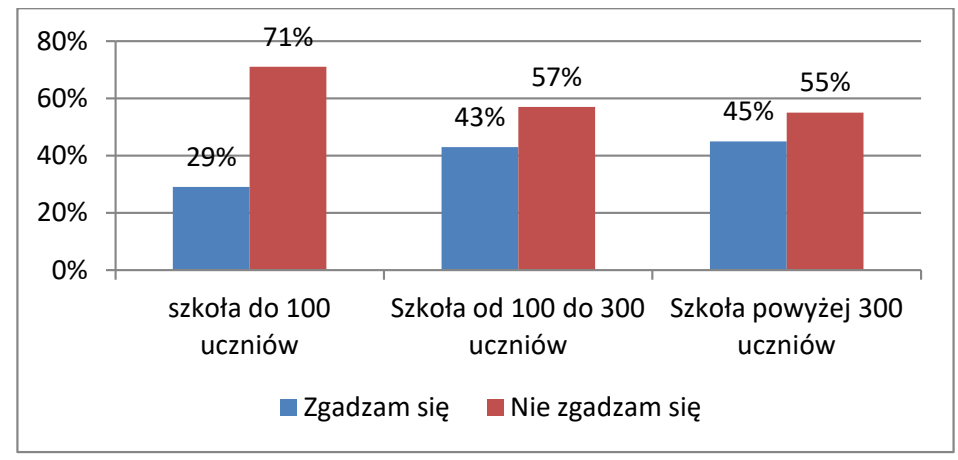

Źródło: badania własne

Wyniki pokazują delikatną tendencję: im więcej uczniów w szkole, tym bardziej nauczyciele w niej uczący są skłonni przyznawać, że sukces szkolny ucznia to wynik „szkolnego”, sztampowego sposobu myślenia. W małej szkole łatwiej o indywidualizację nauczania, tym samym łatwiej docenić (i dostrzec) to, co uczeń rzeczywiście myśli, czuje, wie.

Czy istnieje związek pomiędzy takim sposobem myślenia nauczyciela a jego stażem pracy? Wyniki na kolejnym wykresie. 
Wykres 7.

Stosunek badanych do tezy „Myślę, że uczniowie musza się nauczyć pewnego «szkolnego sposobu myślenia» odpowiadania na pytania, by odnieść sukces w szkole" a staż pracy badanych

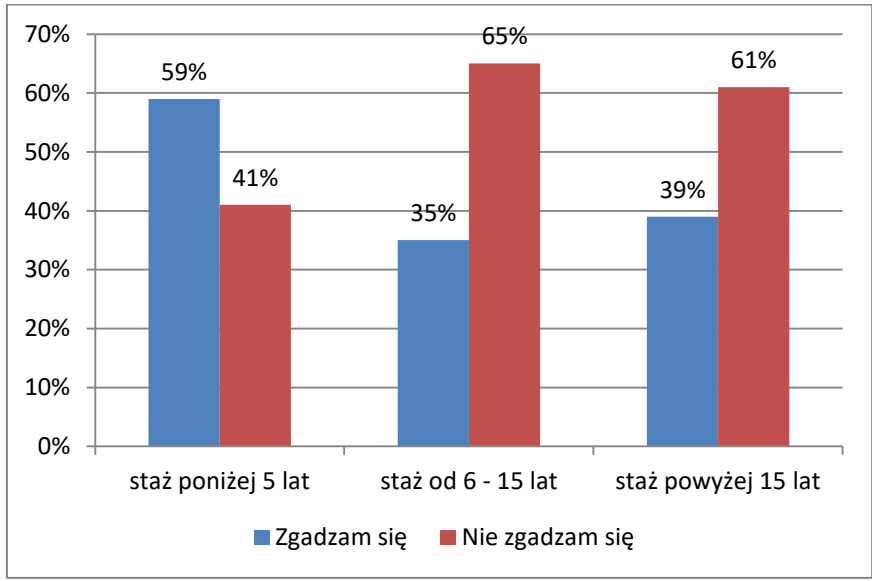

Źródło: badania własne

Po raz kolejny staż pracy okazał się ważną zmienną. Większość młodych nauczycieli nie wierzy w sukces szkolny, bez „szkolnego sposobu myślenia” i „wiedzy szkolnej” rozumianej jako reprodukowanie informacji. Tylko w tej grupie zaznacza się przewaga osób skłaniających się ku zaproponowanej tezie.

Jeżeli weźmiemy pod uwagę poziom kształcenia, na jakim uczy nauczyciel, to z wymienioną tezą zgadza się blisko co trzeci (sic!) (29\%) badany nauczyciel edukacji wczesnoszkolnej i prawie połowa (48\%) nauczycieli uczących w klasach starszych.

Kolejne z twierdzeń dotyczyły metod pracy nauczycieli i programu nauczania. 
Wykres 8.

Stosunek badanych do stwierdzenia: „Myślę, że metody pracy, których używam na lekcji, wspieraja samodzielne myślenie u uczniów"

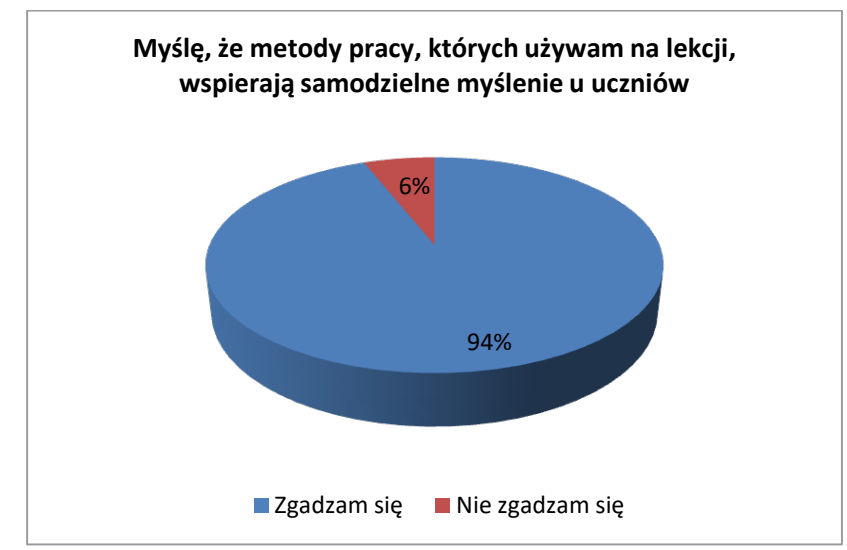

Źródło: badania własne

Jedynie $6 \%$ badanych twierdzi, że ich metody pracy nie do końca wspierają samodzielne myślenie ucznia. Można zadać pytanie, czy nie stoi to w sprzeczności z wdrażaniem do „szkolnego sposobu myślenia”, o jakim wspomniano wcześniej. Warto zatem przyjrzeć się, jakiego rodzaju metody pracy stosują badani nauczyciele. Wśród najczęściej stosowanych w praktyce szkolnej metod pracy nauczyciele wskazują (ze względu na możliwość zaznaczenia dwóch odpowiedzi, wyniki nie sumują się do 100\%):

- pogadankę (233 wskazania),

- pracę z książką (223 wskazania),

- dyskusję (179 wskazań),

- metody problemowe (135 wskazań),

- gry dydaktyczne (131 wskazań),

- metody aktywizujące (111 wskazań),

- wykład (80 wskazań),

- metody projektu (58 wskazań).

Badani wybierają takie, a nie inne metody pracy przede wszystkim dlatego, że są one, ich zdaniem, najbardziej efektywne (64\%) i nauczyciele w tych metodach czują się najlepiej - 26\%. Nie bez znaczenia jest też to, że uczniowie je lubią (56\%) i przyzwyczaili się do nich - 12\%. Ponadto taki dobór metod pracy wynika z rodzaju nauczanego przedmiotu: „rodzaj przedmiotu, jakiego uczę, narzuca mi taki styl pracy” - 33\% badanych, bądź z warunków organizacyjnych: „klasy są 
zbyt liczne, by pracować innymi metodami” - 8\%. Swoich zwolenników ma też opinia, że realizacja programu wyklucza zabawę i eksperymenty - $15 \%$.

W tym kontekście nie dziwi wynik przedstawiony na wykresie 9 .

Wykres 9.

Stosunek badanych do stwierdzenia: „Nie mam czasu na metody aktywizujące, bo sa czasochłonne, a ja muszę realizować program"

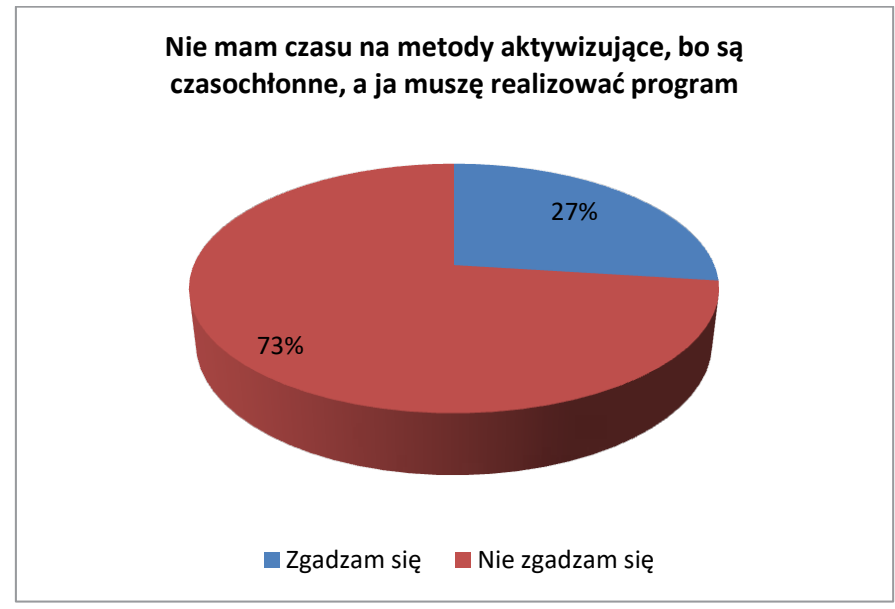

Źródło: badania własne

Blisko jedna trzecia badanych uważa metody aktywizujące za nie dość dobre dla realizacji programu, pamiętając o wynikach badań prezentowanych wcześniej, dotyczących roli nauczyciela jako „dostarczyciela wiedzy”. Ten wynik nie dziwi i jest logiczną konsekwencją takich założeń. Interesująco przedstawiają się powyższe wyniki w odniesieniu do zmiennych niezależnych (staż pracy, wielkość szkoły i poziom kształcenia). 
Wykres 10.

Stosunek badanych do stwierdzenia: „Nie mam czasu na metody aktywizujace, bo sa czasochłonne, a ja muszę realizować program" a poziom nauczania, na jakim pracuja badani

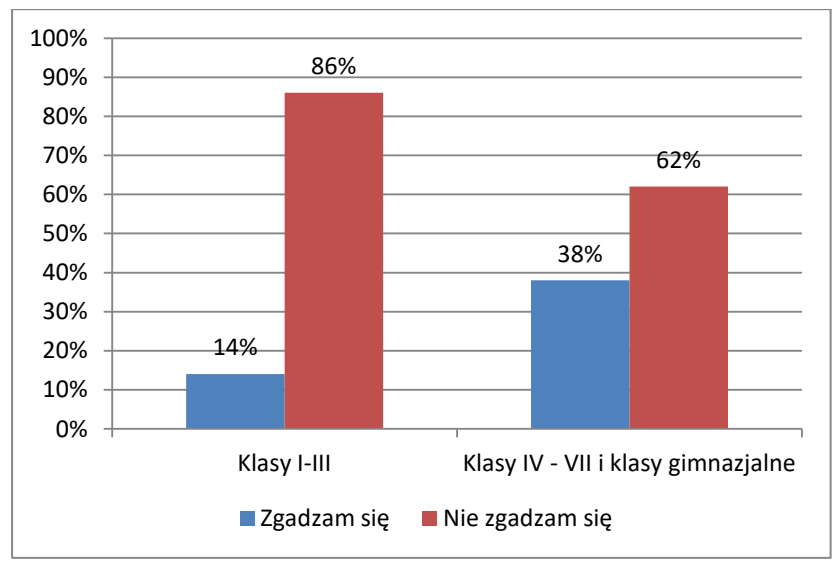

Źródło: badania własne

Zdecydowaną większość w grupie nauczycieli zgadzających się z powyższym twierdzeniem stanowią nauczyciele uczący klasy IV i wyższe. Jednakże niepokojący jest fakt, że 14\% badanych nauczycieli klas I-III również „musi realizować program" i nie ma czasu na aktywizację uczniów.

Wielkość szkoły w tym przypadku nie miała znaczenia. Interesująco przedstawiają się wyniki w kategorii stażu pracy badanych. Przedstawiam je na wykresie 11.

Wykres 11.

Stosunek badanych do stwierdzenia: „Nie mam czasu na metody aktywizujace, bo sq czasochłonne, a ja muszę realizować program" a ich staż pracy

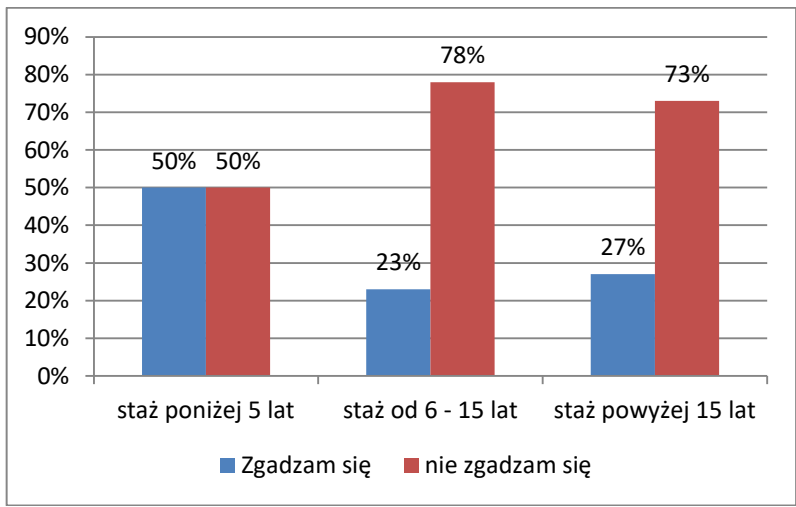

Źródło: badania własne 
Jeżeli chodzi o staż pracy badanych, w grupie osób zgadzających się z powyższą tezą szczególnie silnie reprezentowani są bardzo młodzi nauczyciele, połowa badanych o stażu poniżej 5 lat boi się (?), nie potrafi (?) stosować metod aktywizujących i stawia je w opozycji do wymogu realizacji programu (sic!)

Na poniższym wykresie przedstawiono stosunek badanych do idei kreatywności uczniów w szkole.

Wykres 12.

Stosunek badanych do tezy: „Kreatywność ucznia jest dobra na przedmiotach artystycznych, na pozostałych musi się podporzadkować, bo przecież trzeba realizować program"

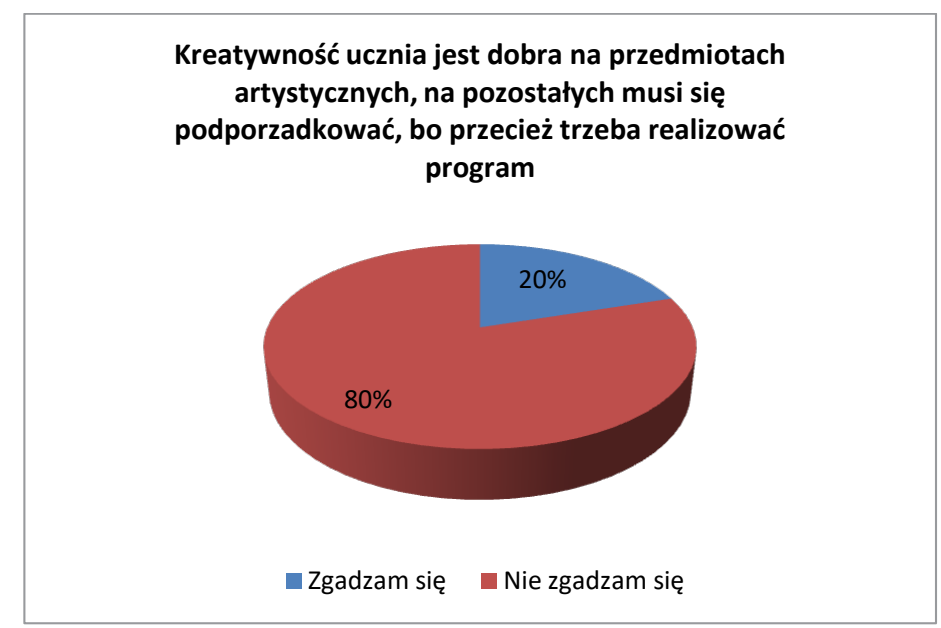

Źródło: badania własne

Co piąty badany zgadza się z twierdzeniem, że „kreatywność ucznia jest dobra na przedmiotach artystycznych, na pozostałych musi się podporządkować, bo przecież trzeba realizować program". Badania wykazały brak związku między wielkością szkoły, w jakiej pracuje badany, a podzielaniem powyższego twierdzenia. 
Wykres 13.

Stosunek badanych do tezy: „Kreatywność ucznia jest dobra na przedmiotach artystycznych, na pozostałych musi się podporządkować, bo przecież trzeba realizować program" a poziom nauczania, na jakim pracuje badany

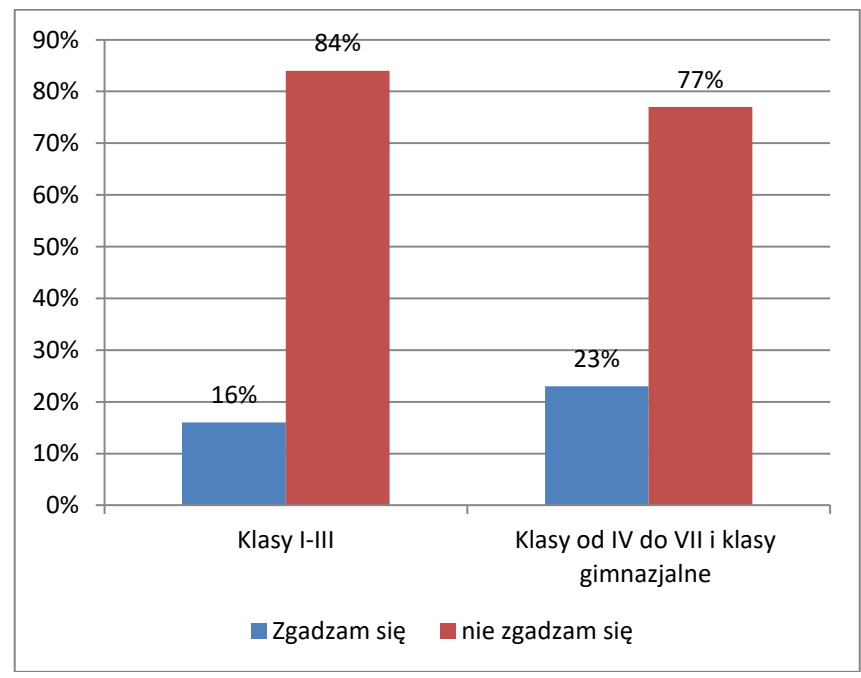

Źródło: badania własne

W przypadku poziomu nauczania rysuje się spodziewana niewielka przewaga nauczycieli klas starszych (66\%), zgadzających się z tym stwierdzeniem. Zadziwiające (i szokujące!) jest jednak to, że co trzeci badany zgadzający się z tym stwierdzeniem to nauczyciel klas początkowych, który rozumie edukację przede wszystkim jako podporządkowanie dzieci realizacji programu, nie pozwalając na ich kreatywność. Wyniki te są szczególnie niepokojące, gdy zdamy sobie sprawę z deklaratywności badań ankietowych, tendencji do autoprezentacji, szczególnie wśród nauczycieli.

Biorąc pod uwagę staż pracy badanych nauczycieli, tendencja jest podobna jak w przypadku metod aktywizujących, chociaż nie tak silna. Wyniki przedstawiam na poniższym wykresie. 
Wykres 14.

Stosunek badanych do tezy: „Kreatywność ucznia jest dobra na przedmiotach artystycznych, na pozostałych musi się podporządkować, bo przecież trzeba realizować program" a ich staź pracy

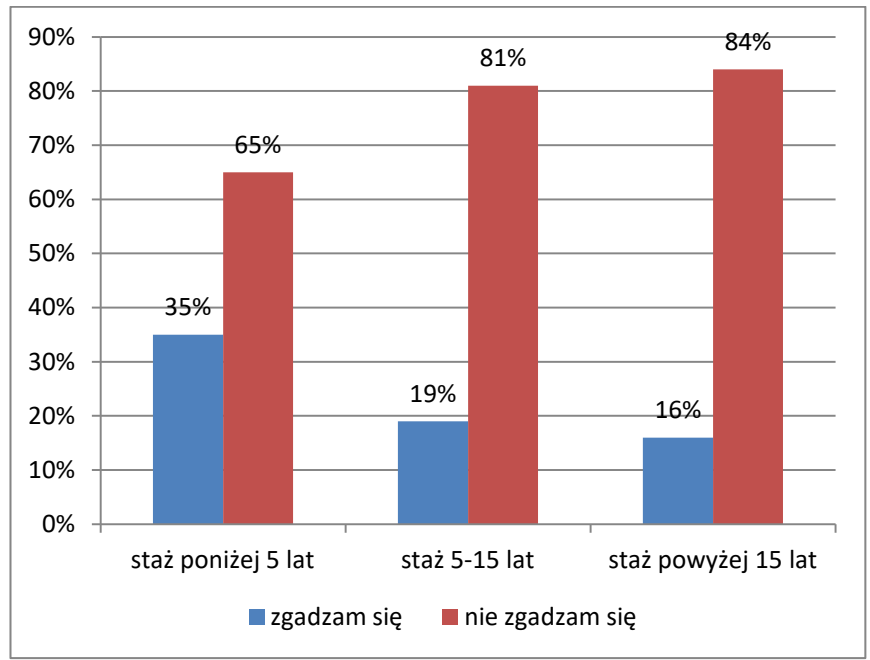

Źródło: badania własne

Podobnie jak w przypadku stosunku do metod aktywizujących, można zauważyć tendencję: im krótszy staż pracy, tym nauczyciele są skłonniejsi do większego skupienia na przekazie informacji niż na rozwijaniu kreatywnego myślenia u swoich uczniów.

\section{WNIOSKI}

W opinii badanych nauczycieli, pomimo permanentnej reformy, szkoła ciągle jeszcze nie do końca jest miejscem rozwijania kreatywności i samodzielności myślenia ucznia, tak niezbędnej do świadomego funkcjonowania we współczesnym świecie.

Wciąż mamy w szkołach wielu nauczycieli, którzy rozumieją swoją rolę jako przekaz wiedzy, nie potrafią, nie wierzą (?) w skuteczność stosowania metod aktywizujących. Z drugiej strony wielu $\mathrm{z}$ nich jest przekonanych o konieczności wdrażania ucznia do „szkolnego sposobu myślenia”, które to w rzeczywistości edukacyjnej, w jakiej przyszło żyć uczniom, ich zdaniem, daje im szansę na osiągnięcie edukacyjnego sukcesu. Takie przekonania bez wątpienia będą przekładać się na praktykę edukacyjną. Patrząc z tej perspektywy, szkoła staje się miejscem 
odizolowanym, nauczyciele doskonalą warsztat nauczania, a uczniowie doskonalą swoiste kompetencje uczniowskie, polegające na rozwijaniu metod interpretacji i adekwatnego (czytaj zgodnego z zamysłem nauczyciela) odczytywania materiału, jaki otrzymują od nauczyciela. Ta izolacja od środowiska może też przybierać postać nieprzystawalności nie tylko treści i metod, ale też efektów kształcenia do „realnego” świata. To jak uczenie pływania bez wody - tej trafnej metafory używa John Dewey (2006) na zobrazowanie metod wychowania szkolnego w ich stosunku do potrzeb społecznych.

Badania wykazały związek osobistych teorii nauczycieli z ich stażem pracy, wielkością szkoły i poziomem nauczania, na jakim pracuje nauczyciel. Okazuje się, że wśród najmłodszych nauczycieli jest najwięcej sceptyków, jeżeli chodzi o możliwości rozwijania samodzielności myślenia i kreatywności wśród uczniów. Jest to ważny wniosek w kontekście kształcenia nauczycieli. Z drugiej strony należy pamiętać o deklaratywności tego typu badań oraz o dążeniach autoprezentacyjnych badanych, szczególnie wśród nauczycieli. Być może najmłodsi byli po prostu bardziej szczerzy.

\section{LITERATURA}

Bennett, K.P., Le Compte, M.D. (1990). The Way Schools Work. A Sociological Analysis of Education. New York - London: Longman.

Dembo, M.H. (1997). Stosowana psychologia wychowawcza. Warszawa: WSiP.

Dewey, J. (2006). Szkoła i dziecko. Warszawa: Żak.

Dusza, B. (2018). Indywidualne teorie nauczycieli jako element kultury szkoły. Edukacja - Technika - Informatyka, 2(24), 248-253. DOI: https://doi.org/10.15584/ eti.2018.2.34

INDIVIDUAL PEDAGOGICAL THEORIES OF TEACHERS ABOUT THE SCHOOL AS THE PLACE OF DEVELOPMENT OF CREATIVITY, INDEPENDENT THOUGHTS AND ACTIONS OF STUDENTS (RESEARCH REPORT)

Abstract: Introduction: In studies about school many different categories are used. In presented
research I use the individual pedagogical theory of teachers category. These theories, being
the effect of, among others, knowledge gained from studies, proffesional experiences, beliefs,
stereotypes, have a crucial impact on their work at school. Purpose: The text is the report
of research conducted in 2019 among elementary school teachers $(N=550)$. The aim of the 
study was the discovery of individual pedagogical theories of teachers releated to school, as the place of development of creativity, independent thinking and actions of the student. Method: Method of diagnostic survey via self-constructed questionnaire was used in the research. Results: The results that were aquired indicate that $43 \%$ of surveyed teachers are convinced that the key job of the school is the relay of knowledge and not development of independence and creativity of students. Their personal theories on this matter differ based on the size of school, work experience and education level. What is disturbing is that $40 \%$ of them believe that, to achieve school success, the development of "school way of thinking” in students is necessary. Conclusions: In this way a paradoxiacal reality is revealed in which the school system doesn't expect students to cope well with living in the world and doesn't prepare them for it, but expects competences of the students needed for them only to survive in the system.

Keywords: school, teacher, individual pedagogical theory of teachers, creativity of the student, independent thinking of the student 